\title{
THE EFFECT OF AUDITOR SWITCH TOWARD THE FIRM VALUE AND EARNING PERSISTANCE.
}

\section{DODIK JULIARDI, DUDUNG MA'RUF NURIS, FATHMAWATI ZAHROH}

\begin{abstract}
The present study aims at examining the effect of audit quality measured by auditor switch on firm value and earnings persistence. The present study was conducted on public service companies which were listed on Indonesian Stock Exchange in 2010 - 2015, with 82 sample companies. The data was obtained through secondary data from Indonesian capital market directory and simple regression analysis for the data analysis.

The result indicates that auditor quality has significant effect on firm value. The quality of an auditor has significant effect on earnings persistence. The Study limitation in term of the coefficient of determination because the independent variable of auditor quality is not the only one that can affect the firm value and earnings persistence. Therefore, it is suggested for futher research to add another independent variable in the future.
\end{abstract}

Keywords : auditor quality, value of the firm, earning persistence, Public Accounting Firm.

\section{Introduction}

Since Indonesian government issued a stipulation that every company that will be listed on the Indonesia Stock Exchange must be audited first by an independent auditor, the demand for audit services is increasing because audit services can improve the quality of accounting information. Basically, the role of independent auditor is to know the level of fairness of the financial statements, whether the presentation is based on accounting principles generally accepted by public or not. The assessment of financial statements is conducted by auditor through finding a material misstatement. Audit provided serves to reduce agency costs because it can increase the accuracy and efficiency of the contract between the principal and the agent. 
Regulation of the Minister of Finance No. 17 / PMK.01/ 2008 which was issued by the government as a response to make PAF (Public Accounting Firm) remain independent, the provision of audit services of financial statement information is limited to 6 fiscal years in a row and by public accountant for 3 fiscal years in a row. This regulation was issued considering that there are many cases of accounting violations which involve auditors. For example, the collapse of PAF Arthur Andherson in maintaining independence in America in 2001 was a message received by governments in various countries to enact auditor rotation as a rule. With this regulation, there is a consequence of moving from one PAF to another PAF. The existence of this regulation is reinforced by Dias (2009) and Giri (2010) that too long audit engagement period will lead the quality and competence of auditors to decrease. It means that if the audit engagement with the client takes long time, the auditors will tend to pay more attention to the client's interest than the public interest.

The study aims to examine the extent to which public service companies listed on IDX from 2010 to 2015 which use PAF services have complied with PMK No. 17/ PMK.01/ 2008 about Mandatory Auditor Switching, considering the issuance of that regulation is to refine the old rules. In this connection, the focus of this study is on the types of auditor switching caused by voluntary auditor factor (voluntary auditor switching).

Signaling theory states that people within a company have better information superiority as well as are faster than outside investors Akerlof (1970). Therefore, management is obliged to convey information about the state of the company to the owner. The information is in the form a signal of success or failure, related to the operations of company. This study examines the quality of auditors as measured by auditor switching on the firm values of public service companies listed on IDX from 2010 to 2015. Based on the signaling theory, a company that has been auditted by a reputable public accounting firm can provide an assurance to be trusted because reputed PAF always prioritizes its professionalism in order to maintain the reputation of PAF, so that PAF will always provide the best service for the users. 
Several studies have examined the auditor quality and the value of firm. One of them is Juliardi (2012), who examined auditor quality and the value of firm; found that auditor quality influences the value of firm, likewise with other researchers like Titman and Truemens (1986), Datar et al. (1991), Klapper and Love (2002), as well as Fan and Wong (2005). This study differs from the study which was conducted by Juliardi (2012) in terms of auditor quality measurement. In the study conducted by Juliardi (2012), the quality of the auditor was measured by the audit market or the number of PAF clients, while in the research conducted by Damayanti and Sudharma (2008), auditor quality was measured by using auditor switching. The quality of auditors in this study was measured by using the measure of auditor switching. Auditor switching was also used by others researchers conducting the previous studies, such as Damayanti and Sudharma (2007), Wijayani and Januarti (2011), Chadegani (2011); Pratitis (2012) Mahantara (2013); Dwiyanti and Sabeni (2014); and Ruroh (2016). This study is different from the previous studies; previous studies examined the size of auditor switching as a dependent variable, whereas this study examines the size of auditor switching as an independent variable.

This study was inspired by the study which was conducted by Pratitis (2012) arguing that companies that often change their public accounting firm or auditors will get a negative response from shareholders because auditor switching lead the company to bear a high burden at the beginning of the commissioning, so that the audit fee of the new public accounting firm increases. Given the shareholders as funders for the operations of company, in order to remain funded, then the perception of the company must be maintained as well as possible. Therefore, these two variables are connected, namely the quality of auditors, measured by auditor switching, and the value of firm.

Based on signaling theory, public accounting firm can provide signal of information to the users outside the company in order to reduce information asymmetry (Watss and Zimmerman, 1981). The financial statements audited by public accounting firm have better reputation in terms of their credibility and are able to demonstrate the actual condition of the company. This is because reputable public accounting firm has a good image in the eyes of community as it has superior resources and competences in 
producing financial statements which have better quality accounting information. Financial statements which have high quality of information will be able to give a signal to its users to know the earnings persistence. Increasing the quality of information also increases the earnings persistence.

The explanation above provides a reason for linking the quality of auditors and the earnings persistence in addition to some of the earlier studies that underlie those relationships. Juliardi (2012) also found that auditor quality has no effect on the earnings persistence. It is similar to the research which was conducted by Permana (2015) that connects the reputation of public accounting firm and earning quality. Therefore, this study will re-examine the quality of auditors against the earnings persistence. The difference of this study with the study conducted by Juliardi (2012) is in terms of auditor quality measurement; in his research, Juliardi used audit market share while this research used public accounting firm and auditor switching.

From the background and the results of the previous studies above, the research questions in this study are:

(1) Does the quality of auditor affect the value of firm?

(2) Does the quality of auditor affect the earnings persistence?

\section{Theoretical Review and Hypothesis Development}

Agency theory applies when the scale of business of a company grows larger, which makes the owner not able to self-manage the operational activities of the company. The owners, consisting of founders and shareholders of the company, then give trust to the manager as an agent to act on behalf of all operational decisions of the company for the best interests of the owners and shareholders (Berle and Means, 1932). The separation of ownership and control in large-scale company leads agency issues, in the form of conflicts between agents and principals because they are basically individuals who think that their interests must be met. This situation often causes managers to act opportunistically, leading to high agency costs. 
This difference of interest widens the information asymmetry between the principal and the agent. Most of actions done by agency are not in accordance with the principal's interests and thus lead to violations of contracts which have been agreed previously. As a result, the principal lacks trust in agents and requires independent parties as mechanism of supervision. The independent auditor is the right profession to provide a supervision and inspection on the part of the owner or shareholder (Fan and Wong, 2005). Audits are useful for reducing agency costs through mechanisms by ensuring the quality of financial statements. Therefore, audit can guarantee the accuracy of the contract and the efficiency between the principal and the agent.

\section{Quality of Auditor}

There are many definitions of quality of auditor, some of which are stated by Angelo (1981), namely the probability that auditor (1) finds a violation in the accounting system and (2) reports the violation, so that the quality of auditor will be determined by his level of competence and independence. Another measure of auditor quality is the size of public accounting firm (Firth and Lian Tan, 1998). Kallapur et al. (2010) measured the quality of auditors as the size of audit market share. Ming (2007) in China used the size of big 10 public accounting firms. Chan et al. (2007) used auditor switching as a measure of auditor quality. Carey and Simnet (2006) used the measure of the existence of profit value. Carcello and Nagy (2004) used a fraudulent rate. Dechow and Dichev (2002) used the accrual quality as a measure of auditor quality. The measure of the quality of auditors used in this study is similar to the measure used by Chan et al (200t), which is quality of auditor measure as an audit switching.

\section{Auditor Switching as a Measure of Auditor Quality}

Auditor switching is PAF or public accounting firm switching which is conducted by company. Auditor switching is divided into 2 namely mandatory auditor switching and voluntary auditor switching. Mandatory auditor switching is defined as the auditor switching due to a regulation. The regulation of public accounting firm requires companies to use the service of another public accounting firm after using the services of a public accounting firm for 6 years in a row and the services of AP after 3 years in a 
row (Regulation of the Minister of Finance No. 17/ PMK.01/ 2008 about Public Accountant Services). Voluntary auditor switching is done by public accounting firm voluntarily, outside the existing regulations. This type of switching is usually due to two possibilities; the company dismisses the auditor or because the auditor has submitted resignation letter. The cause of auditor switching was confirmed by Mardiyah (2002) stating that two factors that influence auditor switching are client factors (client-related factors), namely: financial difficulties, failed management, ownership change, Initial Public Offering (IPO), and auditor-related factors, namely: audit fees and quality of audit.

\section{Hypotheses}

Based on signaling theory, the company that is audited by reputable public accounting firm can provide and show signals of information to potential investors about the success or failure of the company's operations (Akerlof,1970). A reputable public accounting firm can provide assurance that the audit results are more reliable and prioritize professionalism in order to maintain the reputation of the public accounting firm. This characteristic is only owned by a reputable public accounting firm or highquality audit. A company that moves from a public accounting firm which is not reputable to a reputable public accounting firm will be responded positively by market. The increase in the market responds or increase in the number of potential investors who respond to it can increase the stock price of the company. Based on the explanation above, then the formulated hypotheses are:

\section{$\mathrm{H1}$ : The quality of auditor affects the value of firm}

Signaling theory states that public accounting firm acts as a provider of information to outsiders due to information asymmetry (Watts and Zimmerman, 1981). Reputable public accounting firm is believed to have excellence in terms of skill and expertise; therefore, it is trusted by the community in generating reports that have good quality of accounting information. The financial statements which are audited by reputable public accounting firm is believed to be more reliable and reflect the actual financial condition of the company. A company that moves from a non-reputable public 
accounting firm to a reputable public accounting firm will give signal to investors in order to know the earnings persistence because if a company moves from a non-reputable public accounting firm to a reputable firm will lead to more accurate persistence value. If the earnings persistence increases, the ability of profit will be more possible to be predicted (predicted value). Based on the explanation above, the formulated hypotheses are as follows:

\section{H2: The quality of auditor affects the earnings persistence}

\section{Research Method}

This study belongs to explanatory research, which is a research that will analyze the influence of the independent variables to the dependent variable. The relationship to be analyzed is the effect of auditor quality on the value of firm and earnings persistence. In addition, this study is expected to explain the extent to which public service companies which use the services of public accounting firm have complied with the regulation of PMK No.17/ PMK.01/ 2008 about auditor switching obligation.

The research design is presented in figure 1 below:

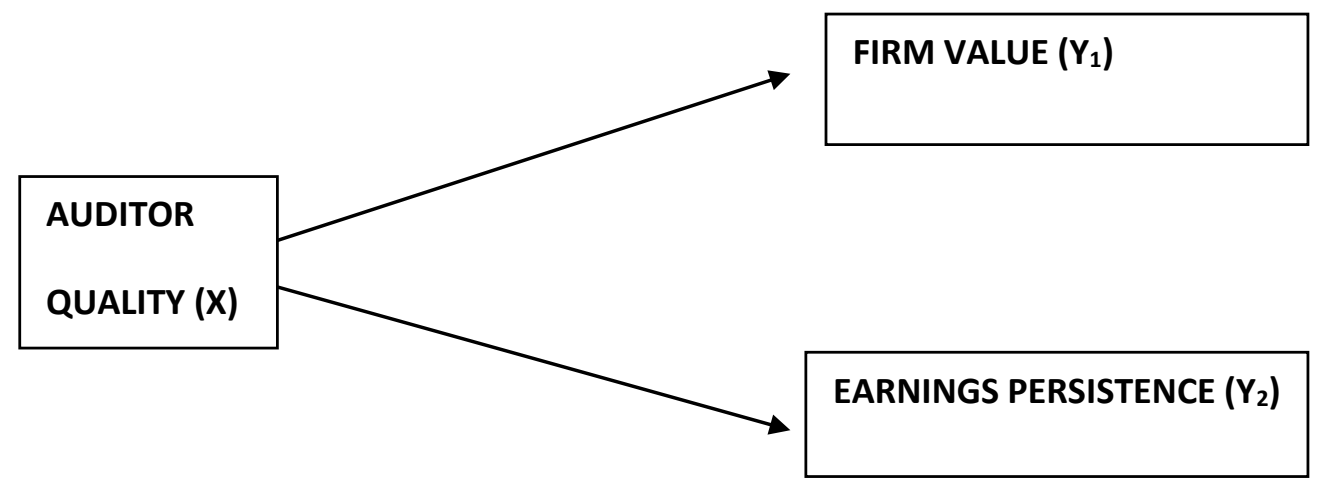

Figure1. The Relationship between Independent Variable and Dependent Variable

The study was conducted on 107 public service companies listed on Indonesia Stock Exchange as the population in this study. So, 642 observations were obtained. The sampling technique used is purposive sampling based on criteria as follows: (1) 
Public service companies listed in 2010 - 2015, (2) Public service companies which are listed continuously from 2010 to 2015, (3) Complete data about information of auditor switching, corporate profits, and number of shares. (4) The company has a positive profit and has never experienced a loss. (5) The data does not have outliers. From the sampling, there are 61 eligible public service companies obtained after eliminating companies that experienced outliers because the data is not normal.

Variable quality of auditor is measured by using dummy variable 1 and 0.1 indicates auditor switching from big four public accounting firm to big four public accounting firm or auditor switching from non-big four public accounting firm to big four public accounting firm. 0 indicates auditor switching from big four public accounting firm to non-big four public accounting firm or switching non-big four public accounting firm to non- big four public accounting firm. Variable of firm value is measured by market value per share to market to book value. Variable of earnings persistence is measured by an autoregressive model of earnings persistence with data between 2010 and 2015.

Hypothesis testing between auditor quality and firm value as well as auditor quality and earnings persistence is done through two stages of simple regression analysis as follows:

$$
\begin{aligned}
& F V=\alpha+A Q_{1} \ldots \ldots(1) \\
& E P=\alpha+A Q_{2} \ldots \ldots(2)
\end{aligned}
$$

Note:

$\mathrm{FV}=$ Firm Value

$A Q=$ Auditor Quality

$\mathrm{EP}=$ Earnings Persistence

\section{Findings and Discussions}

Table 1. The following is descriptive statistics analysis results in order to know the characteristics of data. 
Table 1. Descriptive Statistics

\begin{tabular}{llllll}
\hline Variable & N & Minimum & Maximum & Mean & Std. Deviation
\end{tabular}

$\begin{array}{llllll}\text { AQ } & 130 & 0 & 1.00 & 0.5769 & 0.49596 \\ \text { FV } & 130 & 0.14 & 16.34 & 2.0612 & 2.42008 \\ \text { EP } & 130 & 0.35 & 0.79 & 0.5643 & 0.12572\end{array}$

Table 1 above shows that the minimum $A Q$ value is 0 and the maximum $A Q$ value is 1 , with mean of 0.5769 and standard deviation of 0.49596 . From 61 companies, there are 28 companies which had auditor switching and those who did not have auditor switching are 33 companies. This proportion can be seen in table 2 below

Table 2. Descriptive Statistics

\begin{tabular}{||l|r|r|r|r|}
\hline X4 & N & Mean & $\begin{array}{c}\text { Std. } \\
\text { Deviati } \\
\text { on }\end{array}$ & $\begin{array}{c}\text { Std. Error } \\
\text { Mean }\end{array}$ \\
\hline Have no auditor & 33 & 77.97 & 0.5769 & 0.4596 \\
switching (0) & & 75 & & \\
Have auditor switching & 28 & 81.02 & 3.9740 & .67174 \\
$(1)$ & & 86 & 8 & \\
\hline
\end{tabular}

FV variable has a min-max value of $0.14-16.34$ with an average of 2.0612 and a standard deviation of 2.42008, while EP variable has a minimum value of 0.35 and a maximum of 0.79 . The average result obtained is 0.5643 with standard deviation of 0.12572

\section{Simple Linear Regression Analysis}

Regression analysis aims to determine the relationship between independent variables and the dependent variable. Relationship to be tested is the influence of auditor quality variable on firm values and the influence of auditor quality variable on earnings persistence. This study used a simple linear regression test because it has only one independent variable. 
Table 3. Simple Linear Regression Test

\begin{tabular}{|c|c|c|c|c|c|c|c|}
\hline \multirow[t]{2}{*}{ Model } & \multicolumn{2}{|c|}{$\begin{array}{c}\text { Unstandardized } \\
\text { Coefficients }\end{array}$} & \multirow{2}{*}{\begin{tabular}{|c|}
$\begin{array}{c}\text { Standardized } \\
\text { Coefficients }\end{array}$ \\
Beta
\end{tabular}} & \multirow[t]{2}{*}{$t$} & \multirow[t]{2}{*}{ Sig. } & \multicolumn{2}{|c|}{$\begin{array}{l}\text { Collinearity } \\
\text { Statistics }\end{array}$} \\
\hline & $B$ & $\begin{array}{l}\text { Std. } \\
\text { Error }\end{array}$ & & & & Tolerance & VIF \\
\hline (Constant) & .108 & .119 & & .901 & .369 & & \\
\hline$A Q$ & .331 & .157 & .183 & 2.108 & .037 & 1.000 & 1.000 \\
\hline
\end{tabular}

a. Dependent Variable: FV

Based on the table above, regression equation generated is as follows:

$$
F V=0.108+0.331^{\star} A Q
$$

Interpretation of the equation above is:

$\alpha=\mathbf{0 . 1 0 8}$ means that when there is no independent variable at all, average FV value obtained is $0.108 \%$

$\boldsymbol{\beta}=\mathbf{0 . 3 3 1}$ means that if $A Q$ is 1 , then $F V$ will increase by $0.331 \%$. In other words, difference of $F V$ when $A Q=0$ and $A Q=1$ is $0.331 \%$

Table 4 Simple Linear Regression Test

\begin{tabular}{|c|c|c|c|c|c|c|c|}
\hline \multirow[t]{2}{*}{ Model } & \multicolumn{2}{|c|}{$\begin{array}{c}\text { Unstandardized } \\
\text { Coefficients }\end{array}$} & \multirow{2}{*}{\begin{tabular}{|c|}
$\begin{array}{c}\text { Standardized } \\
\text { Coefficients }\end{array}$ \\
Beta
\end{tabular}} & \multirow[t]{2}{*}{$\mathrm{T}$} & \multirow[t]{2}{*}{ Sig. } & \multicolumn{2}{|c|}{$\begin{array}{l}\text { Collinearity } \\
\text { Statistics }\end{array}$} \\
\hline & $B$ & $\begin{array}{l}\text { Std. } \\
\text { Error }\end{array}$ & & & & Tolerance & VIF \\
\hline 1 (Constant) & -.696 & .029 & & 24.257 & .000 & & \\
\hline$A Q$ & .171 & .038 & .371 & 4.526 & .000 & 1.000 & 1.000 \\
\hline
\end{tabular}

a. Dependent Variable: EP

Based on the table above, regression equation generated is as follows:

$$
E P=0.696+0.171^{\star} A Q
$$

Interpretation of the equation above is:

$\alpha=\mathbf{0 . 6 9 6}$ means that when there is no independent variable at all, average EP value 
obtained is $0.696 \%$

$\boldsymbol{\beta}=\mathbf{0 . 1 7 1}$ means that if $A Q$ is 1 , then $E P$ will increase by $0.171 \%$. In other words, difference of $E P$ when $A Q=0$ and $A Q=1$ is $0.171 \%$.

\section{Hypothesis \\ Partial Test (T test) \\ The Influence of Auditor Quality (AQ) on Firm Value (AQ)}

Based on table 3, it can be seen that the quality of auditors affect the value of firm. This result can be proved by $A Q$ variable having $t$ test value of 2.108 , greater than $t$ $(0.05,128)=1.978$ and sig value $(0.037)$ which is less than $5 \%$. Therefore, hypothesis one which states that the quality of auditors affects the value of firm is acceptable. The results of this study are in accordance with the signaling theory which states that reputable public accounting firms can provide and display signals in form of information to potential investors about the success or failure of the company's operations. It can be mean that when a company moves from non-reputable public accounting firms to a reputable public accounting firms, it will be responded positively by market. On the contrary, moving from reputable public accounting firms to non-reputable public accounting firms will decrease the value of firm. The higher the market responds or the more potential investors who respond to it can increase the stock price of the company. The results of this study are in accordance with the study which was conducted by Juliardi (2012) and Damayanti and Sudharma studies, proving that quality of auditor influences the value of firm. In contrast, the results of this study are not in line with the study which was conducted by Pratitis (2012).

\section{The Influence of Auditor Quality (AQ) on Earnings Persistence (EP)}

Table 4 shows that the quality of auditors influences the earnings persistence. The result is shown by regression analysis result, the value of $F$ count obtained is 20.487 , which is bigger than $F_{(0.05,1,128)}=4,195$, and significance of $F$ test $(0,000)$ which is smaller than $5 \%$; therefore, $\mathrm{H}_{0}$ is rejected. In addition, $\mathrm{AQ}$ variable has a t test value of 4.526, which is greater than $t(0.05,128)=1.978$ and the sig value $(0.000)$ is less than $5 \%$. Therefore, the second hypothesis which states that the quality of auditors affects the earning persistence is acceptable. The results of this study are in accordance with 
signaling theory that public accounting firm acts as a provider of information to outsiders because of information asymmetry (Watts and Zimmerman, 1981). The financial statements audited by public accounting firm are more reliable and reflect the actual financial condition of the company. This means that a company that moves from a nonreputable public accounting firm to a reputable public accounting firm will give signal investors in order to know the earnings persistence because if a company moves from a non-reputable public accounting firm to a reputable public accounting firm, its persistence value will be more accurate. The higher the earnings persistence, the profit will be more possible to be predicted. The results of this study were not in accordance with the study which was conducted by Juliardi (2012) and Permana (2012), which proved that auditor quality has no effect on earnings persistence.

\section{Conclusion and Limitation of Study}

The conclusions of this study are: 1) Auditor quality affects the value of firm, and 2) Auditor quality affects earnings persistence. This study has the disadvantage in term of the coefficient of determination because the independent variable of auditor quality is not the only one that can affect the firm value and earnings persistence as there are other variables beyond this study that can be predictors. For further research, it is suggested to use other variables besides auditor quality, for instance financial difficulties, failed management, ownership change, Initial Public Offering (IPO), and auditor-related factors, namely: audit fees and quality of audit. 


\section{REFERENCES}

Akerlof G.A. 1970. The Market for Lemons: Quality Uncertainty and the Market Mechanism. Quarterly Journal of Economics

Atmaja, Lukas Setia. 2002. Manajemen Keuangan, Ed. II Penerbit Andi Yogyakarta.

Ashbaugh, H., and Warfield T.D., 2003. Audit as a Corporate Government Mechanism: Evidence from the German Market. Journal of International Accounting Research 2: 1 21.

Barth, M.E., W.H. Beaver and W.R. Landsman. 2001. The Relevance of value Relevance Literature for Financial Accounting Standard Setting : Another Review. Journal of Accounting and Economics. Vol. 31: 77 - 104.

Berle, Adolp and Means, Gardiner, 1932. The Modern Corporation and Private Property, New York, N.Y., MacMillan.

Bringham, E.F. and J.F. Houston. 1999. Manajemen Keuangan. Edisi Bahasa Indonesia, Jakarta: Erlangga.

Chan, K.H., Lin, K.Z., and Zhang, Fang. 2007. On the Association between Changes in Corporate Ownership and Changes in Auditor Quality in A Transitional Economy. Journal Of International Accounting Research. Vol. 6, No. 1, pp. 19-36

Chadegani, Arezoo A., Mohamed, Zakiah M., \& Jari, Azam 2011. The Determinat Factors of Auditor Switch among companies listed on Tehran Stock Exchange. Internasional Research of Journal of Finance and economics (80) 158-168.

Chow, C.W., and Rice, S,J., 1982 Qualified Audits Opinions and Auditor Switch. The Accounting Review 57: 326-335.

Damayanti S.dan Sudharma, M. 2007. Faktor-faktor yang mempengaruhi Perusahaan Berpindah kantor Akuntan Pulik. Pontianak : Simposium Nasional Akuntansi 11.

Dwiyanti, R. Meike Erika \& Sabeni 2014. Faktor-faktor yang Mempengaruhi Auditor Switching secara voluntary. Diponegoro Journal of Accounting. 3(3) 1-8

DeAngelo, L., 1981. Auditor Size and Auditor Quality. Journal of Accounting and Economics 3(3): 183-199

Fan, J.P.H. and Wong, T,j., 2002. Corporate Ownership Structure and the Informativeness of Accounting Earnings in East Asia. Journal of Accounting and Economics 33: 401-426 
Francis, J.R., and Wilson, E.R., 1988. Auditor Changes: A Joint Test of Theories Relating to Agency Costs and Auditor Differentiation. The Accounting Review 63(October):663682

Jensen, M., \& Meckling, W. 1976. The Agency Cost Of Free Cash Flow, Corporate Finance and Takeover, American Economic Review

Juliardi, Dodik. 2012. Pengaruh Leverage, Konsentrasi Kepemilikan, dan Kualitas Auditor Terhadap Nilai perusahaan dan Persistensi laba Pada Perusahaan Publik Industri Manufaktur yang Listed di Bursa Efek Indonesia. Disertasi. Universitas Airlangga.

Jones, C.P. 2000. Investment Analysis and Management, $7^{\text {th }}$ Edition, New York; John Wiley \& Son, Inc.

Keiso, Donanld E., Jerry J. Weygandt and Terry D. Warfield 2002. Akuntansi Intermediete, Ed. 10, penerbit Erlangga Jakarta

Leland, H.E. and D.H. Pyle, 1977. Information asymmetries, Financial structure, and Financial Intermediation. Journal of Finance 32, 371-387.

Lipe, R.C. 1990. The Relation between stock returns and given alternative information. The Accounting Review 65:49-71.

Mahantara, A.A. Gede Widya 2013. Faktor-faktor yang mempengaruhi Pergantian Kantor Akuntan Publik pada Perusahaan yang Terdaftar di Bursa Efek Indonesia. Jurnal Universitas Udayana, 2 (10): 724-736

Porter, G. 1992. Accounting Earnings Announcement, Institutional Investors Concentration and Common Stock Returns. Journal of Accounting Research, Vol. 30. No. 1 p. 146-155

Pratitis, yanwar T, 2012. Auditor Switching: Analisis berdasar Ukuuran KAP, Ukuran Klien dan Financial Distress.Accounting Analysis Journal: 27-32

Ruroh, Farida Mas., \& Rahmwati, Diana 2016. Pengaruh Pergantian Manajemen, Kesulitan Keuangan,Ukuran KAP, dan Audit Delay terhadap Auditor Switching. Jurnal Nominal 5(2) : 68-80.

Scott, W.R. 2006. Financial Accounting Theory. Scarborough: Prentice Hall

Simunic,, D.A. and Stein, M.T., 1987. Product Differentiation in Auditing : Auditor Choice in the Market for Unseasoned New Issues, The Canadian Certified General Accoutants Reasearch Foundation, Vancouver (1987).

Sudarwan, M. And T.J. Forgarty. 1996. "Culture and Accounting in Indonesia: An empirical Examination. The International Journal of Accounting 31, 463 - 481. 
Tuanakotta, Theodorus, M., 2007. Setengah Abad Profesi Akuntansi, Ed 1, Jakarta:Penerbit Salemba Empat.

Watts, Ross L. and Jerols L. Zimmerman, 1986. Positive Accounting Theory. Englewood Clieffs, New Jersey, Prentice Hall.

Weston, J.F., and T.E. Copeland, 2002, Manajemen Keuangan. Edisi Kesembilan, Jilid Pertama, Alih Bahasa Wasana dan Kribandoko, Binarupa Aksara, Jakarta.

Wijayani, Evi Dwi \& Januarti, Indira. 2011. Analisis faktor-faktor yang mpengaruhi Perusahaan di Indonesia Melakukan Auditor Switching. Aceh Simposium 